\title{
LA EXPOSICIÓN HISTÓRICO-AMERICANA DE MADRID DE 1892 Y LA ¿AUSENCIA? DE MÉXICO
}

POR

DENÍ RAMÍREZ LOSADA

En 1892 se celebró en España el IV Centenario del Descubrimiento de América. En el marco de este festejo destacó, sin duda, la Exposición Histórico Americana de Madrid no sólo por su enorme relevancia politica, cultural y cientifica que, hasta ahora, se ha estudiado poco, sino por todo aquello que significó para México en particular. El artículo centra su interés en destacar, por un lado, la singularidad de los festejos colombinos y, por el otro, mostrar que la participación de México en la Exposición Histórico-Americana constituyó todo un hito científico en la antropología mexicana. La investigación se llevó a cabo, fundamentalmente, sobre la copiosa documentación encontrada en el Archivo General de la Administración, Alcalá de Henares.

Palabras Clave: IV Centenario, Exposición Histórico-Americana, México, Museo Nacional, antropología.

Es sabido que en 1892 se celebró en España el IV Centenario del Descubrimiento de América. Muy sabido es, también, que dentro del marco de este gran festejo hubo una intensa actividad cultural que quedó plasmada no sólo en los diversos congresos que se llevaron a cabo o en la infinidad de artículos y publicaciones dedicadas a temas americanos, sino en la celebración de varias exposiciones internacionales de las cuales destaca la Exposición Histórico-Americana de Madrid por todo aquello que significó para países como México o Colombia, por ejemplo. Sabido es, tal vez, que dicha conmemoración no tuvo el éxito esperado. Pero menos sabido es que, precisamente, la celebración del IV Centenario, y en especial la Exposición Histórico-Americana, tuvieron una relevancia política, cultural y «científica» mucho mayor de la que hasta ahora se les ha dado. No sabemos si se debe a un olvido involuntario o a una franca actitud de ninguneo, pero lo cierto es que la singularidad de la 
Exposición Histórico-Americana y, sobre todo, la participación de México en ella no han sido valoradas en su justa dimensión. Así las cosas, este trabajo inicial, que se inscribe dentro de una investigación más amplia ${ }^{1}$, pretende rescatarlas del olvido.

Durante la celebración del IV Centenario del Descubrimiento de América ${ }^{2}$ se llevaron a cabo once congresos internacionales ${ }^{3}$, tres grandes exposiciones de carácter internacional, amén de una vehemente actividad editorial que quedó recogida en los principales diarios y revistas de la época ${ }^{4}$. Las exposiciones aludidas son: la Exposición Histórico-Americana ${ }^{5}$, la Exposición Histórico-Europea ${ }^{6}$ y la Exposición de Bellas Artes ${ }^{7}$. Las dos primeras fueron inaugu-

1 Investigación que, a su vez, se inscribe en el proyecto «Ingenieros Sociales. La construcción del método y el pensamiento antropológicos en Europa e Iberoamérica, siglo XIX» (BSO2001-2341), financiado por la Dirección General de Investigación del Ministerio de Ciencia y Tecnología. La estancia de investigación (SB2003-0213) llevada a cabo en el Departamento de Historia de la Ciencia del Instituto de Historia del Consejo Superior de Investigaciones Científicas (CSIC), ha sido financiada por la Secretaría de Estado de Universidades e Investigación del Ministerio de Educación y Ciencia. Agradezco a Jesús Bustamante por sus invaluables comentarios y sugerencias.

2 Existen pocos trabajos dedicados al estudio del IV Centenario del Descubrimiento de América. Entre ellos podemos destacar los de Bernabéu Albert, XLIV/174 (Madrid, julio/diciembre 1984): 345-366; 1987; 2006: 9-65. Así como los trabajos de Calderón Quijano, 1986; 18 (Madrid, 1990): 93-166.

3 Los congresos celebrados fueron: IX Congreso Internacional de Americanistas; Congreso Pedagógico Hispano-Portugués-Americano; Congreso Jurídico Iberoamericano; Congreso Geográfico Hispano-Portugués; Congreso Militar Hispano-Portugués-Americano; Congreso Mercantil Hispano-Americano-Portugués; Congreso Literario Hispano-Americano; Congreso de Librepensadores, Congreso Católico; Congreso Africanista y Congreso Espiritista.

4 Se editaron, para la ocasión, El Centenario. Revista Ilustrada la cual constituía el órgano oficial de la Junta Directiva del IV Centenario del Descubrimiento de América; España-Portugal. Revista popular colombina y España y América. Revista Ilustrada de Bellas Artes, Ciencias y Literatura. Diversas revistas publicaron números especiales con motivo de la conmemoración, entre ellas podemos citar Círculo de Bellas Artes, La Ilustración Española y Americana y Revista Contemporánea.

5 En esta exposición participaron: Alemania, Argentina, Austria, Bolivia, Colombia, Costa Rica, Chile, Dinamarca, República Dominicana, Ecuador, Estados Unidos, España, Guatemala, México, Nicaragua, Noruega, Perú, Portugal, Suecia y Uruguay.

${ }^{6}$ Debido a la falta de medios adecuados, y de tiempo, para llevar a cabo una exposición industrial y agrícola de los países hispanoamericanos, Antonio Cánovas del Castillo propuso que se celebrara la Exposición Histórico-Europea como complemento de la Exposición Histórico-Americana. La exposición retrospectiva de objetos de arte de los siglos XV, XVI y primera mitad del siglo XVII tenía por objeto mostrar «el estado de la cultura artística de Europa, y señaladamente de España y Portugal, en los tiempos del descubrimiento y la conquista de América». «Documentos Oficiales. Exposición Histórico-Europea de Madrid», II (Madrid, 1892): 181.

7 La celebración de la Exposición Nacional de Bellas Artes coincidía con la conmemora- 
radas oficialmente el 12 de noviembre y no el 12 de septiembre de 1892 como se tenía previsto. La fecha de clausura estaba estimada, en principio, para el 31 de diciembre de 1892. El retraso en la inauguración pospuso la clausura oficial para el 3 de febrero de 1893. Sin embargo, tanto la Comisión del IV Centenario como la Junta Directiva de la misma a través del Presidente del Consejo de Ministros, Práxedes Mateo Sagasta, le propusieron a la reina regente María Cristina, que en virtud de que las Exposiciones Históricas habían sido «gallarda muestra de los tesoros que España posee y fuente inagotable para el estudio de la Antropología, la Arqueología y la Historia», permanecieran abiertas hasta el primero de julio de $1893^{\circ}$. La iniciativa fue aceptada y la reina en el Real Decreto de 25 de marzo de 1893 manifestó, en el artículo cuarto, que «Las Exposiciones Históricas se refundirán en una sola bajo la denominación de "Exposición Histórico-Natural y Etnográfica" que permanecerá abierta al público hasta el treinta de junio próximo» ${ }^{9}$. Esto es, las dos Exposiciones Históricas fueron sustituidas por la Exposición Histórico-Natural y Etnográfica que cerró sus puertas el 30 de junio de $1893^{10}$.

Al leer la escasa literatura que existe sobre la Exposición Histórico-Americana en general y la participación de México en particular ${ }^{11}$, llaman la aten-

ción del IV Centenario, por lo mismo, se acordó darle un carácter internacional y, para ello, se expidió el Real Decreto de 4 de octubre de 1891. Participaron: Francia, Portugal, España, Austria, Suecia, Inglaterra, Estados Unidos, Baviera, Rusia, Brasil y Bélgica. Bernabéu Albert, 1987: 102.

8 Proyecto de Real Decreto que el Presidente del Consejo de Ministros, de acuerdo con el mismo Consejo, tiene la honra de someter a la aprobación de V.M., 25 de marzo de 1893. Archivo General de la Administración, Alcalá de Henares (AGA), Presidencia, caja 3608.

9 Real Decreto de 25 de marzo de 1893, AGA, Presidencia, caja 3608. Cabe señalar que los gastos que generara la nueva Exposición se cubrirían en la forma establecida para ambas Exposiciones por la Junta Directiva del Centenario. La nueva Junta Directiva quedó integrada por el Ministro de Fomento como Presidente; los Delegados generales de las Exposiciones Histórico-Europea e Histórico-Americana; José Bragat y Gerardo Mullé de la Cerda en concepto de Vocales; el Subsecretario de la Presidencia del Consejo de Ministros y Ezequiel Moreno Lopez de Ayala, como Secretarios.

10 Debido al interés de los países latinoamericanos por llevar a la World's Columbian Exposition of Chicago (1893) los objetos que presentaron en Madrid, muchas de las colecciones de la Exposición Histórico-Natural y Etnográfica se quedaron sin sus mejores piezas. No obstante, dichas ausencias fueron sustituidas por innumerables piezas que no habían sido expuestas aún y que se encontraban en las bodegas del edificio de la Biblioteca y Museos Nacionales de Madrid. Carta del Delegado General al Presidente de la Junta Directiva del IV Centenario, 17 de diciembre de 1892, AGA, Presidencia, caja 3602.

11 Sobre la participación de México en la Exposición Histórico-Americana se pueden leer referencias breves en diversos trabajos que versan, más que nada, sobre la historia de la antropología en México o la historia del Museo Nacional de México. No obstante, existen dos ar- 
ción dos ideas casi reiterativas. Por un lado, la presencia de México es, o bien denostada, o bien minimizada a su máxima expresión (aunque la frase en sí pueda parecer una enorme contradicción). Por otro, se desconoce, casi por completo, el entramado cultural, político y científico que se puso en marcha para no «deslucir» (por decirlo de alguna forma) la participación de México. El empeño puesto tanto por el gobierno de Porfirio Díaz como por la Junta Colombina, nombrada ex professo para la exposición, fue reconocido y elogiado por la Junta Directiva del IV Centenario la cual, en uno de sus informes sobre los resultados alcanzados en sus gestiones, señaló que México había superado las esperanzas de la Junta pues «su gobierno además de abrir un crédito ampliable, de cien mil pesos, para concurrir a la exposición con lo más notable que existía en Museos, establecimientos públicos o en manos de particulares, había formado subcomisiones con las personalidades más influyentes del país. Ello constituía, por tanto, un alto ejemplo que México daba a América y al mundo» ${ }^{12}$.

La participación de México no se reduce tan sólo al envío de renombradas personalidades a los congresos, obras de arte o una banda militar ${ }^{13}$. Tampoco, a una exclusiva manifestación, en México, del españolismo de la reacción mexicana ${ }^{14}$. Mucho menos a una exposición de segundo orden ${ }^{15}$, al menos no para la ciencia mexicana que mostraba su alto nivel de conocimiento en la materia. Y si bien la Exposición Histórico-Americana no tuvo el impacto ni las dimensiones de las habituales exposiciones internacionales decimonónicas, no menos cierto es que la exposición de Madrid fue, en gran medida, el preámbulo y ensayo de lo que México expondría en la sección de etnología de la World's Columbian Exposition of Chicago (1893). Esa sección que, curiosamente, resultó ser notable por su enfoque etnográfico ${ }^{16}$. La participación de México en la Exposición Histórico-Americana constituye, digámoslo de una vez, todo un hito en temas políticos, culturales y, sobre todo, científicos, como trataré de demostrar a lo largo del trabajo.

tículos de Georgina Rodríguez que se ocupan del tema en cuestión: Rodríguez Hernández, 13 (México, septiembre/diciembre 1997): 25-31; 5/13 (México, mayo/agosto 1998): 123-144.

12 Relato de los principales resultados que en sus gestiones alcanza la Junta Directiva y que siguen al del 12 de abril próximo pasado, 26 de mayo de 1892, AGA, Presidencia, caja 3602 .

13 Rodríguez, 1994: 127-162.

14 Muriá, 3 (México, septiembre/diciembre 1985): 123-136.

15 Granados, 2005: 121.

16 Tenorio Trillo, 1998: 247. 


\section{PARTICIPACIÓN DE MÉXICO EN LA EXPOSICIÓN HistÓRICO-AMERICANA}

Desde muy temprano México hizo eco de la invitación hecha por el gobierno español a todos los países de América Latina (incluido Estados Unidos) para que participaran en los festejos por el IV Centenario del Descubrimiento de América. El gobierno mexicano creó una comisión especial dedicada a organizar, clasificar y preparar los materiales y colecciones que se presentarían en la Exposición Histórico-Americana de Madrid. Dicha comisión, establecida el 9 de mayo de 1891, estuvo integrada por Joaquín García Icazbalceta, quien fuera nombrado presidente de la misma por los demás miembros de la comisión, Alfredo Chavero, José María Vigil, José María de Agreda y Sánchez, Francisco del Paso y Troncoso y, como secretario, Francisco Sosa ${ }^{17}$. Los miembros decidieron dar a la comisión el nombre de Junta Colombina ${ }^{18}$, siendo el Museo Nacional de México su lugar habitual de trabajo.

Las actividades desarrolladas por la Junta Colombina fueron múltiples y variadas. Primero, se dio a la tarea de seleccionar, dentro de la copiosa colección de objetos del Museo Nacional, todas aquellas piezas que estuviesen duplicadas o que no habían sido expuestas al público; se obtuvo, así, un número considerable de objetos arqueológicos y etnográficos que serían expuestos en Madrid. Aunada a esta primera selección se acordó comprar, junto con el $\mathrm{Mu}-$ seo, la colección arqueológica reunida en Puebla durante varios años por el comerciante alemán José Dorenberg ${ }^{19}$. El códice mixteco que contenía la colección fue nombrado, por iniciativa de Alfredo Chavero y el mismo Del Paso y Troncoso, Códice Colombino el cual, en unión con otros códices y objetos que se fueron adquiriendo, fue publicado por la Junta Colombina bajo el título de Antigüedades Mexicanas en homenaje a Cristóbal Colón y como recuerdo de la fecha que se iba a celebrar ${ }^{20}$. Dicha publicación la componían, por un lado, una rica colección de objetos pequeños procedentes de Chiapas que estaban cubiertos de admirables relieves. Por otro, la reproducción cromolitográfica de los originales de cinco códices, a saber: el Códice Colombino; el Códice Porfirio Díaz, que consiguió el presidente Porfirio Díaz para la Junta; el Códice Ba-

17 Oficio de la Secretaría de Estado y del Despacho de Justicia e Instrucción Pública de México, 2 de junio de 1891, AGA, Relaciones Exteriores, legajo 214.

18 Del Paso y Troncoso, 1892a, tomo I: 5. Galindo y Villa, VI (México, 1892-1893): 301-323.

19 Del Paso y Troncoso, 1892a, tomo I: 7. La colección contenía más de tres mil piezas, no todas fueron seleccionadas. Y, a decir de Francisco del Paso y Troncoso, no sólo era importante por el gran número de piezas, sino por cuatro valiosos ejemplares en particular: tres propulsores (para lanzar dardos) que los mexicanos llamaban átlatl y un códice mixteco.

20 Del Paso y Troncoso, 1892a, tomo I: 8. 
randa, que se conservaba en la Biblioteca Nacional y pasó al Museo Nacional para su publicación por orden del Secretario de Justicia Joaquín Baranda (de ahí el nombre del códice); el Códice Dehesa, cedido por su dueño al Museo Nacional y, por último, el Lienzo de Tlascala, cuyas acuarelas fueron proporcionadas por Alfredo Chavero ${ }^{21}$.

La preocupación por mostrar «el glorioso pasado de México como nación indígena y como colonia» hizo que la Junta Colombina le encargara al ingeniero Antonio García Cubas la elaboración de una Carta geográfica del Imperio Mexicano y demás naciones descubiertas y conquistadas por los españoles durante el siglo XVI en el territorio perteneciente hoy a la República Mexicana. La carta quedó dividida en tres partes: I.- Geografía antigua de México: se muestran las divisiones territoriales de las diversas «nacionalidades que tenían asiento en el país de Anáhuac, desde los soberbios imperios Mexicano y Tarasco, hasta la humilde nación Chontal en el sur, ó la indómita y semibárbara tribu Tepehuana en el norte». II.- Descubrimientos y conquistas: se muestran los itinerarios de los descubridores por mar y los exploradores por tierra durante casi todo el siglo XVI. Quedaron trazadas, por ejemplo, las expediciones marítimas de Hernández de Córdoba y Grijalva en el Mar del Norte (Golfo de México), las expediciones de Hernán Cortés a las Hibueras u Honduras; las expediciones de Nuño de Guzmán a Nueva Galicia o la expedición de Francisco Vázquez de Coronado a Cíbola o Nuevo México. III.- Viajes y descubrimientos en el Mar del Sur (Pacífico): abarca desde 1527 en adelante y se citan las navegaciones a Filipinas de Ruy López de Villalobos y Miguel López de Legazpi a través del Mar del Sur ${ }^{22}$.

La Junta Colombina deseosa de mostrar un panorama, lo más amplio posible, de México pidió a los gobernadores de todos los estados de la República que enviaran fotografías de ruinas y «tipos indígenas» de sus respectivos estados. Algunas de las series fueron tomadas por fotógrafos como Hilario Olaguíbel, Emilio Leal, Rafael García (fotógrafo de la Comisión Científica de Cempoala), Francisco Río de la Loza, el padre Aquiles Gerste o el austriaco Teobert Maler; así como, en conocidos estudios fotográficos de la época: el de Bernal en Hermosillo o el de Pedro Guerra en Mérida, Yucatán ${ }^{23}$. Otras más fueron tomadas por Alfredo Laurent, fotógrafo francés con estudio fotográfico en Guaymas, Sonora; Desiderio Lagrange, fotógrafo de origen francés establecido en Nuevo León; Celerino Gutiérrez, fotógrafo de Uruapan, Michoacán; Antonio W. Rieke, fotógrafo de origen germano quien junto a Alex y Mendo-

21 Del Paso y Troncoso, 1892a, tomo I: 8.

22 Del Paso y Troncoso, 1892a, tomo I: 16. Galindo y Villa, I (México, 1922): 305-579.

23 Del Paso y Troncoso, 1892b, tomo II: 253 y ss. 
za, la Gran Fotografía Alemana y C. Palacios enviaron las colecciones de Chiapas; B. Valverde, fotógrafo de Chihuahua; la sociedad Hierro y Bonilla de Zacatecas; Elias A. Bonine, fotógrafo establecido en Pasadena, California hacia 1885, y Francisco Herrera, fotógrafo español con estudio en Tepic, Nayarit ${ }^{24}$.

De igual forma, la Junta consiguió dos riquísimas colecciones particulares. La primera, de objetos eclesiásticos, fue proporcionada por Eulogio G. Gillow, arzobispo de Antequera de Oaxaca. La segunda, con objetos arqueológicos, etnográficos y antropológicos, fue facilitada por el presbítero Francisco Plancarte ${ }^{25}$, cura de Tacubaya quien, además, prestó su colección de cráneos tarascos. Esta última interesó al antropólogo francés Ernest Théodore Hamy quien manifestó, a su paso por la exposición de Madrid, el deseo de que dicha colección figurara en la obra que estaba preparando sobre Craneología ${ }^{26}$.

En el Museo Nacional se habilitaron talleres de imprenta, dibujo, litografía, carpintería y vaciados, entre otros. Para la ocasión se hizo el vaciado de los catorce monolitos prehispánicos más notables de la afamada Galería de Monolitos del museo ${ }^{27}$. Se montó, además, un taller fotográfico con el fin de reproducir todos aquellos objetos que no podían ser enviados a Madrid debido a la imposibilidad de transportarlos por el excesivo peso o por ser demasiado voluminosos y muy frágiles. Por más de cuatro meses estuvo trabajando el capitán Hilario Olaguíbel, fotógrafo de la Secretaría de Guerra y Marina, bajo la inspección de Fernando Ferrari Pérez, jefe de los talleres, en la formación de las más de seiscientas fotografías que se hicieron. El mismo del Paso y Troncoso vigilaba de cerca las tareas y del número total de fotografías escogió doscientas para su reproducción. El excesivo costo de los materiales hizo que sólo se reprodujeran, por el «procedimiento fotocolográfico», cien ejemplares de cada negativo. No obstante, las colecciones completas no fueron enviadas a Ma$\operatorname{drid}^{28}$.

24 Rodríguez Hernández, 13 (México, septiembre/diciembre 1997): 28-29; 5/13 (México, mayo/agosto 1998): 132-133.

25 Para conocer en detalle la colección de objetos etnográficos, arqueológicos y antropológicos de Francisco Plancarte exhibida en la Sección de México durante la Exposición Histórico-Americana de Madrid puede consultarse: Del Paso y Troncoso, 1892c. Todas las piezas (2.800 aproximadamente) fueron compradas por el Museo Nacional al término del certamen.

26 Del Paso y Troncoso, 1892a, tomo I: 18. (La colección fue enviada a París).

27 Dichos objetos, tal y como consta en el Libro de registro de donaciones del Museo Arqueológico Nacional de España, fueron donados por el gobierno de México una vez finalizada la Exposición Histórico Americana. En la actualidad, se exhiben en el Museo de América de Madrid.

28 Del Paso y Troncoso, 1892a, tomo I: 13. 
No conforme con todo ello, la Junta Colombina resolvió realizar varias expediciones arqueológicas y etnográficas que recorrieron distintos estados del país con el fin de aumentar tanto las colecciones arqueológicas, como recopilar el mayor número de objetos etnográficos para dar una idea más clara de «ciertas nacionalidades indígenas importantes que ocuparon en los tiempos prehispánicos varias regiones de nuestra República ${ }^{29}$. La primera de estas expediciones se denominó Comisión Científica de Cempoala ${ }^{30}$, bajo la dirección de Francisco del Paso y Troncoso y se llevó a cabo desde agosto de 1890 hasta marzo de 1891 (aproximadamente) en gran parte del estado de Veracruz. El abundante material arqueológico que se obtuvo enriqueció notablemente los cinco salones que ocupó la Sección de México en el Palacio de Museos, Archivo y Biblioteca Nacionales en Madrid. En la expedición no sólo se descubrió Cempoala, el conocido poblado totonaca de la época de la Conquista, sino que se determinó el sitio exacto de la Villa Rica de la Veracruz, se exploraron los territorios comprendidos entre Papantla y Cotaxtla y se reconoció el Tajín. Como fruto de la expedición, se presentaron en Madrid el plano general de las ruinas de Cempoala y el particular de su templo mayor; así como, cerca de doscientas fotografías que tomó Rafael García, fotógrafo de la expedición, de las cuales el insigne paisajista mexicano José María Velasco ${ }^{31}$ realizó catorce extraordinarios dibujos, a lápiz, de las ruinas.

Una segunda expedición contó con fondos del Museo Nacional, duró tan sólo quince días y se llevó a cabo por la costa de sotavento de Veracruz. Acompañó a Del Paso y Troncoso el auxiliar de la comisión: Francisco Río de la Loza quien obtuvo diversas fotografías de «sitios notables» y objetos arqueológicos de los lugares visitados. La colección fotográfica enriqueció el material expuesto en la sección mexicana. Otras expediciones sí fueron organizadas ex professo por la Junta Colombina. La primera partió a Palenque bajo la dirección de Francisco Río de la Loza y el oficial Pedro Pablo Romero. Otra más se encaminó a Casas Grandes a cuyo cargo estuvo el reverendo Padre Aquiles Gerste. Una tercera, comisionada a Fernando del Castillo, fue a Pa-

29 Del Paso y Troncoso, 1892a, tomo I: 20.

30 Sobre la expedición científica a Cempoala puede consultarse, también: Galindo y Villa, III (México, 1911): XCV-CLXI.

31 Es pertinente señalar que José María Velasco ocupó el cargo de dibujante del Museo Nacional de 1880 a 1889; de dibujante-fotógrafo de 1889 a 1904, año en el que la plaza se dividió en una de dibujante y otra de fotógrafo, ocupando Velasco aquélla hasta 1910. José María Velasco participó, como dibujante, en muchas de las expediciones científicas que se organizaron en el museo. El reconocido artista además de elaborar espléndidos dibujos para los Anales, realizó obras de gran formato que se expusieron en el Museo Nacional. Rico Mansard, 2004: 215 y 343. 
pantla para ratificar y completar las mediciones hechas por Francisco del Paso y Troncoso de la pirámide del Tajín cuya reproducción en madera se expuso en Madrid. A Francisco Plancarte le fue asignada la expedición que partió a Morelia en busca de pinturas tarascas. Las gestiones llevadas a cabo con el gobernador de Michoacán, Aristeo Mercado, dieron como «resultado la entrega de la mejor parte de las colecciones reunidas en el Museo Michoacano» ${ }^{32}$, las cuales complementaron la colección particular de Plancarte. Los últimos expedicionarios fueron el Dr. Manuel Villada quien fue a Guadalcázar (San Luis Potosí) y el profesor Francisco Río de la Loza que, a su regreso de Tabasco, se incorporó a la expedición del estado de Veracruz ${ }^{33}$. Es pertinente señalar que los objetos arqueológicos y etnográficos recabados en las expediciones, toda vez que regresaron de Madrid, enriquecieron los fondos del museo.

Por último, el taller tipográfico del Museo Nacional se amplió y se instaló un taller de litografía. Ello permitió un programa de publicaciones de mayor envergadura y calidad que no sólo se vio reflejado en las publicaciones que presentó México en la Exposición Histórico-Americana, sino en las posteriores publicaciones del museo. Para el evento madrileño se expusieron la monumental obra Antigüedades Mexicanas compuesta por el Códice Colombino; las Obras históricas de D. Fernando de Alva Ixtlilxóchitl, en dos volúmenes, anotados por Alfredo Chavero; una edición de lujo de la Bibliografía Mexicana del siglo XVI, escrita y publicada por Joaquín García Icazbalceta; los Apuntes históricos de México, formados por José Fernando Ramírez; los tomos de los Anales del Museo Nacional; la Invención de la Santa Cruz por Santa Ele$n a$, coloquio en lengua náhuatl traducido al castellano por Francisco del Paso y Troncoso; la Epigrafía Mexicana de Jesús Galindo y Villa y la Carta geográfica del Imperio Mexicano de Antonio García Cubas ${ }^{34}$.

Una vez finalizado el encomiable trabajo de recolección, clasificación y selección de todo el material (cerca de 17000 piezas), bajo el celo profesional que caracterizaba a Francisco del Paso y Troncoso, México estaba listo para participar en la Exposición Histórico-Americana. La delegación mexicana llegó dos meses antes de la inauguración y quedó integrada como sigue: Jefe de la Comisión: Gral. Vicente Riva Palacio, enviado extraordinario y Ministro

32 Dicho museo fue fundado el 26 de febrero de 1886 y estaba dividido en cuatro departamentos: Arqueología, Etnografía, Historia e Historia Natural. Su primer director fue Nicolás León quien, en 1888, empezó a editar los Anales del Museo Michoacano cuyos contenidos de carácter antropológico y etnográfico estaban dedicados, en su mayor parte, a los tarascos. Sánchez y Mijangos, 1996.

33 Del Paso y Troncoso, 1892a, tomo I: 23-27.

34 Galindo y Villa, I (México, 1922): 466-467. 
Plenipotenciario en Madrid ${ }^{35}$; Presidente de la Comisión: Francisco del Paso y Troncoso, director del Museo Nacional de México. Comisionados: Francisco Sosa, miembro de la Real Academia de la Lengua Española de México y Secretario de la Junta Colombina; Manuel Payno, cónsul general en Barcelona; Manuel Gómez Velasco, cónsul en Madrid. Auxiliares: Presbítero Dr. Francisco Plancarte, cura de Tacubaya; Francisco Río de la Loza, profesor de química en el Instituto Médico Nacional de México; Fernando del Castillo, teniente de la plana mayor facultativa de ingenieros; Jesús Galindo y Villa, secretario de la Sociedad Científica «Antonio Alzate» de México. Secretario: Agapito Ortiz de Jiménez.

\section{SINGULARIDAD DE UNA CONMEMORACIÓN}

a) El conflicto por la sede y la naturaleza de la conmemoración: España, Italia y Estados Unidos

Es probable que la celebración del IV Centenario del Descubrimiento de América causara poco entusiasmo en países como Inglaterra o Francia quienes, de hecho, declinaron participar en los festejos organizados por el gobierno español. Pero en países como Italia, Estados Unidos o la misma España, la celebración se convirtió en un apasionado campo de batalla por hacer suyo el Centenario.

Si bien es cierto que los primeros años de vida de la Comisión del IV Centenario se caracterizaron por una inactividad sorprendente, no menos cierto es que desde fechas muy tempranas ya se pensaba en conmemorar con gran esplendor y solemnidad el centenario. Prueba de ello es la carta que se publicó en The Independent el 3 de mayo de 1883, donde el columnista Clarence Winthrop Bowen relata una serie de entrevistas que mantuvo con políticos españoles para conocer sus opiniones al respecto. Así, por ejemplo, para el Duque de Veragua no sólo España y las naciones de América deberían de participar en la celebración, sino que también debía hacerlo Italia — el país que era la cuna de Colón-; así como Inglaterra, Francia y las demás naciones de Europa que ha-

\footnotetext{
35 Vicente Riva Palacio, embajador de México en Madrid desde 1886 hasta 1896, además de participar de manera muy activa en la Junta Directiva española, fue designado delegado general interino de la Exposición Histórico-Americana mientras el secretario general de la misma, Juan Navarro Reverter, estuvo ausente de España. Riva Palacio también fue nombrado presidente de las Exposiciones Militares que se agregaron a la Exposición Histórico-Americana. Carta del Delegado General de la Exposición Histórico-Americana al Presidente de la Junta Directiva, 29 de octubre de 1892, AGA, Presidencia, caja 3602.
} 
bían contribuido ampliamente con la colonización del Nuevo Mundo ${ }^{36}$. Además, añade Winthrop, el Duque creía que era necesario llevar a cabo una sola celebración con la que todas las naciones interesadas pudieran contribuir, convirtiéndola así en una de las más grandiosas y magnas fiestas que se hubiesen llevado a cabo en el mundo; sin embargo, no era partidario de realizar varias celebraciones en distintos países al mismo tiempo ${ }^{37}$.

Esta doble preocupación por la simultaneidad de los festejos y por el país que llevaría el peso de la celebración centenaria continuaría presente en los miembros que integraron la primera comisión del centenario. Así las cosas, comenzaron los contactos con diversas autoridades italianas para conocer los preparativos del gobierno del rey Humberto para celebrar el Cuarto Centenario del Descubrimiento. En la Pro-Memoria, entregada por el embajador de Italia en España, quedó muy claro que hasta ese momento (abril de 1888) Italia sólo había pensado en publicar una obra con todo lo que había escrito Colón; así como, de cuantos documentos pudiesen ilustrar la historia de sus viajes y de su descubrimiento ${ }^{38}$. No obstante, se añadía, el gobierno italiano opinaba que debían celebrarse fiestas tanto en Génova como en España para lo cual deseaban que una comisión de ambos países fijase la época y la manera de llevar a cabo dichas fiestas. La época y la manera de llevar a cabo las celebraciones se convirtieron en un verdadero nudo gordiano pues ambos países no querían que las fiestas se celebraran de manera simultánea, sino que tuvieran lugar con algún intervalo «de suerte que pudieran hacerse como distintas etapas de una gran solemnidad universal» ${ }^{39}$. La controversia no quedó zanjada hasta la creación de la nueva Junta Directiva del Centenario (11 de enero de 1891) cuya presidencia recayó en el presidente del Consejo de Ministros, el conservador Antonio Cánovas del Castillo ${ }^{40}$.

36 Winthrop Bowen, 1889: 7. AGA, Presidencia, caja 3613 (traducción de la autora).

37 Winthrop Bowen, 1889: 7.

38 Pro-Memoria entregada por el Sr. Embajador de Italia en España, relativa a los preparativos que hace el Gobierno del Rey Humberto para celebrar el Cuarto Centenario del descubrimiento de América por Cristóbal Colón, 14 de abril de 1888, AGA, Presidencia, caja 3613. Meses después, la Comisión italiana entregó el proyecto de la Raccolta Colombina.

39 Carta de Don Cristóbal Colón y de la Cerda (Duque de Veragua), Vice-presidente de la Comisión Organizadora del Cuarto Centenario, al Presidente del Consejo de Ministros D. Práxedes Mateo Sagasta, 13 de mayo de 1888, AGA, Relaciones Exteriores, caja 1287.

40 Es preciso señalar que tanto la Comisión del IV Centenario, creada bajo el mando del liberal Sagasta, como la Junta Directiva del Centenario, liderada por el conservador Cánovas, coincidían en que se debía conmemorar el IV Centenario; sin embargo, diferían en la manera de llevar a cabo los objetivos programáticos de la celebración: estimular el patriotismo español y potenciar las relaciones culturales con América Latina. Estas divergencias ideológicas quedaron plasmadas de manera muy clara en los preámbulos de los Reales Decretos de 28 de febrero 
De esta forma, el 16 de marzo de 1892 el embajador de Italia en España le comunicó a Antonio Cánovas del Castillo el período durante el cual sería celebrado en Italia, principalmente en Génova, el centenario de la gesta colombina: desde los primeros días de agosto hasta mediados de octubre, quedando por determinar las fechas exactas de los momentos más importantes del festejo tales como, la inauguración de la Exposición Italo-Americana, la visita de las escuadras amigas al puerto de Génova, entre otras; momentos que quedarían señalados en los días en que los Reyes de Italia decidieran asistir personalmente a dichas ceremonias ${ }^{41}$.

La respuesta de Cánovas no se hizo esperar. En una nota fechada el 1 de abril de 1892, el jefe del gobierno informó que a pesar de que el gobierno de SM la reina regente deseaba mostrar «la más exquisita deferencia hacia el deseo manifestado por el Rey de Italia respecto a que se combinaran las fechas de los festejos conmemorativos, de modo que no coincidieran en los mismos días los unos con los otros», le parecía muy difícil, por no decir insuperable, obtener el resultado que se deseaba ya que para España era «imprescindible necesidad» solemnizar varios aniversarios en fechas fijas. Por tanto, el gobierno español, cuyos primeros festejos iban a celebrarse en Huelva, «no podía prescindir de conmemorar el 2 de agosto la salida del Puerto de Palos de las carabelas que marchaban al Nuevo Mundo y el 3 de agosto el acto de haber salvado las naves la barra o ría de Saltés entrando en el océano». Desde estas fechas, continúa Cánovas, hasta el 12 de octubre en que se solemnizará el aniversario del descubrimiento, fecha también invariable, se inaugurarán las diferentes Exposiciones que se llevarán a cabo en Madrid, se celebrará el Congreso de Americanistas y darán comienzo las diversas fiestas y congresos preparados por diferentes sociedades e individuos. Los días previstos para las inauguraciones oficiales a cargo de la Junta Directiva del Centenario aún estaban por determinarse aunque se procuraría, hasta donde fuere posible, coordinarlas con las fechas de las solemnidades italianas ${ }^{42}$.

Pese a estos reiterados intentos por no hacer coincidir los festejos italianos y españoles, ambos gobiernos decidieron llevar a cabo sus conmemoraciones en aquellas fechas que consideraban cruciales e inamovibles ${ }^{43}$. La superposi-

de 1888, firmado por Sagasta, y de 9 de enero de 1891, firmado por Cánovas. Véanse, también, López-Ocón, 1992: 379-397; Rama, 1982; Bernabéu Albert, 1987.

41 Carta del Embajador de Italia en España al Presidente del Consejo de Ministros D. Antonio Cánovas del Castillo, 16 de marzo de 1892, AGA, Presidencia, caja 3613.

42 Carta de D. Antonio Cánovas del Castillo al Embajador de España en Italia, 1 de abril de 1892, AGA, Relaciones Exteriores, caja 1287.

43 Finalmente, Italia declinó participar en los festejos del IV Centenario, alegó que el rey 
ción de fechas y festejos no restó importancia a las celebraciones españolas las cuales, contrariamente a lo sucedido en Italia, lograron sumar la participación de casi todos los países latinoamericanos, algunos europeos y otros tantos asiáticos. Así las cosas, España dejó clara su supremacía frente a la celebración italiana que sólo buscaba conmemorar la figura de Cristóbal Colón. En Italia las celebraciones quedaron reducidas a una Exposición Italo-Americana de carácter marcadamente nacional, varios festejos en fechas muy precisas y la inauguración, en los primeros días de septiembre, del Congreso Botánico Internacional, el Congreso Pedagógico y el Congreso Geográfico ${ }^{44}$ donde la concurrencia fue más escasa y la resonancia internacional mucho menor. Sin embargo; es preciso señalar que Italia no mostró mayor interés en la celebración del IV Centenario debido a que su política exterior estaba dirigida a consolidar su expansionismo colonial en África en respuesta a la presencia francesa en Túnez, además de reforzar su permanencia en la Triple Alianza conformada por Alemania, el Imperio Austro-Húngaro e Italia.

Pero hay más. La celebración de la gesta colombina tuvo como trasfondo político el proceso de construcción de la identidad nacional española. Ello hizo que España otorgara a la celebración del Cuarto Centenario del Descubrimiento un papel toral en su política exterior ya que no sólo buscaba aumentar su prestigio internacional, sino que intentaba consolidar las relaciones culturales, diplomáticas e, incluso, comerciales con América Latina ${ }^{45}$ en un claro desafío a la política panamericanista que Estados Unidos intentara poner en marcha en la Primera Conferencia Internacional Americana, celebrada en la ciudad de Washington de octubre de 1889 a abril de 1890. Como consecuencia de esto, la historia de la disputa entre España y Estados Unidos, por hacer suyo el centenario, siguió otro derrotero. En la misma carta publicada en The Independent en 1883, Emilio Castelar le comentó a Clarence Winthrop Bowen que la celebración de 1892 era una idea en la que los españoles estaban particularmente interesados y dado que Estados Unidos tenía relaciones amistosas con los países de América, y como cualquier paso que tomara en este o en cualquier otro asunto tendría un peso significativo, él estaría satisfecho con ver a Estados Unidos tomar un papel líder en un evento de tan vasta magnitud como

Humberto deseaba «dedicar todos los recursos de Italia para honrar en su patria nativa la memoria del gran descubridor». Carta del Encargado de Negocios de la Embajada de España en Italia al Ministro de Exteriores, 6 de abril de 1891, AGA, Relaciones Exteriores, caja 1287.

44 Ortiz de Pinedo, II (Madrid, 1892): 85-92.

45 Durante el primer gobierno de la Regencia se reactivó la política exterior española. Segismundo Moret, ministro de Estado, puso especial interés en las relaciones de España con América Latina. 
el aniversario del descubrimiento del Nuevo Mundo ${ }^{46}$. Agrega Castelar que, con toda seguridad, las ceremonias en New York serían imponentes.

Para 1888 el gobierno español cambió de opinión pues la conferencia de Washington le parecía una verdadera amenaza. Le atemorizaba, por un lado, que Estados Unidos monopolizase los mercados latinoamericanos cerrando, así, las puertas a la industria y los capitales españoles y europeos. Por otro, le preocupaba que el programa y los fines de la citada conferencia resultasen fatales para las aspiraciones y la política de España en Latinoamérica. Una intensa política cultural hacia los países de América Latina fue la respuesta del gobierno español quien, por iniciativa de su Ministro de Estado Segismundo Moret, alertó a los representantes diplomáticos españoles de la amenaza que representaba dicha conferencia y planteó la necesidad de celebrar el IV Centenario del Descubrimiento de América. En ese tenor, el embajador de España en Washington señaló que la publicación de los Reales Decretos de 28 de febrero de 1888 ofrecía «a los pueblos hispanolatinos el medio y la ocasión de resistir las atracciones del Norte, y satisfacer sus aspiraciones de aproximación y enlace con la cuna de su cultura y el origen de su civilización». Añadió que de la actividad, el patriotismo y la manera con que supiera llevar a cabo su cometido la comisión encargada de los festejos dependería, en gran medida, el éxito de la política española en América ${ }^{47}$. Política que había encontrado su fórmula y su momento de realización en la celebración del Cuarto Centenario el cual, bajo las apariencias de una solemnidad exterior, envolvía un importantísimo fin político.

Sin embargo, las noticias sobre las ideas y propósitos de los Estados Unidos para celebrar el Centenario de Colón en 1892 preocuparon de manera significativa al gobierno español. Otra vez fue el representante español en Washington quien advirtió que «la actitud adoptada por España con las Repúblicas Hispano Americanas con motivo de la celebración de aquella memorable solemnidad; ha dado nuevo vigor a las aspiraciones políticas de Norte América formuladas desde 1880, bajo la dirección de Mr. Blaine» ${ }^{48}$. Y, si bien, España sentía amenazadas su supremacía en el festejo y su influencia en el conti-

\footnotetext{
46 Winthrop Bowen, 1889: 8-9.

47 Carta del Embajador de España en Washington al Presidente del Consejo de Ministros, 16 de abril de 1888, AGA, Presidencia, caja 3613.

48 Carta del Embajador de España en Washington al Presidente del Consejo de Ministros, 7 de mayo de 1888, AGA, Presidencia, caja 3613. Acompaña la carta la traducción del debate llevado a cabo ante el Comité de relaciones exteriores del Senado norteamericano referente a la celebración del IV Centenario del Descubrimiento de América. AGA, Presidencia, caja 3613.
} 
nente americano; no menos cierto es que Estados Unidos también se sentía amenazado por España tanto en sus relaciones comerciales ${ }^{49}$ y sociales con los países de la zona, como en su «orgullo y decoro» los cuales «exigían que la primera de las naciones europeas, los Estados Unidos [sic], respondieran a este sentimiento tomando la iniciativa en la celebración de este gran acontecimiento histórico de un modo adecuado a la dignidad, grandeza y magnitud del Nuevo Mundo descubierto por Colón» ${ }^{50}$.

No está de más señalar que en Estados Unidos el Comité de la ciudad de New York para la Exposición Internacional de 1892 atribuía al Duque de Veragua y a otros políticos españoles el origen del proyecto de conmemoración estadounidense. William E. D. Stokes, secretario del comité, aludía a la carta aparecida en The Independent en 1883 para defender, ante el Congreso de los Estados Unidos de América, que dicha celebración no sólo debía hacerse con la solemnidad, grandeza y entusiasmo que el caso requería, sino que las fiestas debían llevarse a cabo en la ciudad de New York ya que en la carta aludida todos los «honorables caballeros de España» habían designado a esta ciudad como punto de reunión ${ }^{51}$. Comenzó, así, un cabildeo diplomático que llevó a

49 Las celebraciones de la Primera Conferencia Internacional Americana en 1889-1890 y de la Exposición Internacional de 1893, bajo los auspicios del gobierno estadounidense, comparten un mismo interés económico: la búsqueda de mercados externos para colocar en ellos el exceso en la producción de los Estados Unidos y, así, contrarrestar los capitales europeos y el comercio de los países latinoamericanos con Europa. Para conocer las bases ideológicas de la política panamericanista, pueden consultarse: Arriaga, 1994: 107-126; Connell-Smith, 1982; Ardao, 1986: 157-171.

50 Exposición de las tres Américas, debate ante el Comité de relaciones exteriores del Senado norteamericano referente a la celebración del IV Centenario del Descubrimiento de América, 21 de mayo de 1888, AGA, Presidencia, caja 3613. En Estados Unidos la conmemoración del IV Centenario generó una interesante disputa simbólica no sólo entre «diferentes grupos étnicos», sino también en el mundo académico. Así las cosas, Colón se convirtió en icono de identidad étnica, simbolizó el nuevo mundo y, «en la imagen popular, fue sinónimo de Estados Unidos». Al respecto, véase Handlin, 29 (México, mayo/agosto 1994): 5-26.

51 Carta de William E. D. Stokes, Secretario de The Committee for the International Exposition of 1892, of the City of New York, al Duque de Veragua, 19 de noviembre de 1889, AGA, Presidencia, caja 3613. Cuatro ciudades norteamericanas disputaban la sede de la Exposición Internacional: Washington, New York, Chicago y St. Louis. Finalmente, el 25 de abril de 1890 la ciudad de Chicago fue designada sede de la Exposición Internacional de 1893 tras un intenso e interesantísimo debate en el Congreso de los Estados Unidos. Para conocer con mayor detalle las razones por las cuales se proponía y defendía la ciudad de New York como sede de la Exposición Internacional de 1892, se puede ver el folleto editado por The Committee for the International Exposition of 1892, of the City of New York, Committee on Legislation, 1889, AGA, Presidencia, caja 3613. También pueden verse: Badger, 1979: en especial el capítulo 6; Rydell, 1984. 
ambos países a la búsqueda de una «amistosa cooperación» que asegurara el éxito de las dos celebraciones.

Pese a ello, en el Congreso de los Estados Unidos la Exposición Histórico-Americana de Madrid no despertó mucho interés y la participación de Estados Unidos se vio seriamente amenazada. La delegación que representaría a dicho país en las fiestas del Centenario español tuvo que esgrimir argumentos de peso para lograr una resolución a favor de los presupuestos correspondientes y obtener el apoyo oficial. Finalmente persuadieron al gobierno para que tomara parte en los festejos madrileños no sólo «para asegurar la participación española en la Feria Mundial de Chicago, sino como un aliciente para que España levantara el embargo que existía sobre el puerco estadounidense» ${ }^{52}$. Las colecciones enviadas por Estados Unidos a la Exposición Histórico-Americana resultaron ser testimonio de un cuidadoso y selecto trabajo en antropología, arqueología e historia. Se pudieron apreciar importantes colecciones del Museo Nacional de los Estados Unidos, el Instituto Smithsoniano, la Universidad de Pennsylvania, el Museo Peabody de Arqueología y Etnología Estadounidenses y otras instituciones; además de la colección de la Expedición Hemenway con cerca de 5,000 piezas arqueológicas y antropológicas de las zonas de Nuevo México y Arizona ${ }^{53}$. La delegación quedó integrada por el contraalmirante Stephen B. Luce como comisario general; y los profesores G. Brown Goode del Museo Nacional y James C. Welling, rector de la Universidad de Columbia como comisarios ${ }^{54}$.

Quizás los resultados un tanto limitados, sobre todo para Estados Unidos, que se obtuvieron en la Conferencia de Washington de 1890 en temas como el de la unión aduanera en el continente o el del arbitraje como principio de derecho internacional para la solución de controversias entre naciones demostraron, por una parte, que los países latinoamericanos se consideraban y se trataban diplomáticamente de igual a igual con Estados Unidos pues éste aún no tenía el poder y la influencia que adquirirá en el continente después de la guerra

52 Merle Curti, 55/4 (USA, julio 1950): 833-856 (traducción de la autora). Cabe recordar que Chicago era la ciudad con mayor producción de granos y carne de puerco de Estados Unidos.

53 Fewkes, 1892.

54 Carta de Vicente Riva Palacio al Presidente de la Junta Directiva del Cuarto Centenario del Descubrimiento de América, 16 de junio de 1892, AGA, Presidencia, caja 3602. En esta carta se añade que «indudablemente; el feliz y brillante éxito obtenido en los Estados Unidos a favor de la Exposición Histórico-Americana débese en gran parte al Sr. Campillo, vicepresidente de la Comisión española del Centenario en Washington, que, con su acreditado celo y reconocida ilustración, ha sabido fomentar en aquel país ese espíritu entusiasta que se revela con el anuncio de numerosas e importantes colecciones». 
hispano-norteamericana de 1898. Por otra, que la intensa política cultural que puso en marcha el gobierno español hacia los países latinoamericanos si bien se puede calificar de exitosa a raíz no sólo de la participación de éstos en la celebración del IV Centenario del Descubrimiento, sino al fomento de los lazos e intercambios culturales entre escritores hispanoamericanos y españoles, o al mayor canje de revistas, periódicos y libros, o a la iniciativa de libreros y editores españoles que favorecieron el comercio de exportación de libros a América Latina y estimularon la publicación de las obras de infinidad de intelectuales latinoamericanos ${ }^{55}$; no menos cierto es que dicha política cultural encontró mayor resonancia en países como México o Colombia.

\section{b) La respuesta de los países latinoamericanos: dos casos significativos}

En Colombia, por ejemplo, el gobierno conservador de Carlos Holguín, inmerso en una compleja trama política que determinará la participación o no de Colombia tanto en la Exposición Histórico-Americana de 1892 como en la Exposición de Chicago de 1893, decidió comprar el Tesoro de los Quimbayas con el fin de exponerlo en ambas exposiciones. Sin embargo, en virtud de que España había reconocido la soberanía de Colombia en los territorios de La Guajira, San Faustino y la margen izquierda del río Orinoco en el laudo arbitral firmado el 16 de marzo de 1891 donde quedaron dirimidos los límites fronterizos entre Colombia y Venezuela ${ }^{56}$, el presidente Holguín decidió obsequiar la afamada colección al gobierno español reivindicando, así, su lealtad a la monarquía. Con ello dejó muy claro que Colombia apostaba por un mayor acercamiento a la política hispanoamericana española de corte más conservador ${ }^{57}$. En una carta personal enviada a Antonio Cánovas del Castillo, el presidente colombiano informaba que había «tenido la buena fortuna de poder comprar la colección más completa y más valiosa, toda de oro finísimo, de la

\footnotetext{
55 De esa época data, por ejemplo, la obra de Marcelino Menéndez Pelayo Antología de poetas hispanoamericanos, publicada por la Real Academia Española con motivo del IV Centenario del Descubrimiento de América. Pérez Bustamante, III/1 (Madrid, septiembre 1948): 22-37.

56 Laudo arbitral dirimiendo la cuestión de límites entre Colombia y Venezuela dictado por el gobierno español en Madrid a 16 de marzo de 1891, AGA, Relaciones Exteriores, caja 3144 .

57 El hispanoamericanismo oficial de marcado carácter conservador no es el único que encuentra cabida en los países latinoamericanos. Un hispanoamericanismo de matiz progresista va calando en los intelectuales y políticos tanto españoles como latinoamericanos finiseculares. Para un análisis de las distintas corrientes del hispanoamericanismo español: Pike, 1971; López-Ocón, 1987; Mainer, 1988; Sepúlveda Muñoz, 1994; 2005.
} 
industria de los aborígenes de Colombia. Aunque la he comprado con el especial designio de presentársela al Gobierno de S.M. como una pequeña muestra de nuestro agradecimiento por el servicio que nos prestó sirviéndonos de árbitro en nuestro pleito con Venezuela sobre delimitación de fronteras, esperando que ella adorne algún Museo de Madrid» ${ }^{58}$. Aclaraba que dicha colección debía ser exhibida primero en Madrid, luego en Chicago para después regresar a España y ocupar su lugar en el museo pertinente ${ }^{59}$. Pese a su decisión cuasi personal, el presidente Carlos Holguín no pudo entregar de manera oficial el Tesoro de los Quimbayas; la convulsionada vida política de Colombia y la reapertura de la Exposición Histórico-Natural y Etnográfica en Madrid coadyuvaron a ello. Fue Miguel Antonio Caro, vicepresidente del gobierno conservador de Rafael Núñez, quien lo hizo.

Pero hay más. La compra del Tesoro representó para la Comisión de Exposiciones de Colombia una erogación del $70 \%$ del presupuesto asignado para participar en las exposiciones de Madrid y de Chicago ${ }^{60}$. Esta reducción presupuestaria puso en duda la presencia de Colombia en la Exposición Mundial de Chicago. Duda que despertó comentarios airados en la prensa estadounidense. Ejemplo de ello es el artículo publicado en el diario The Herald de New York donde se dice que «la pordiosera suma de $\$ 40,000$ no es siquiera bastante para levantar un edificio en Chicago, por no decir nada de los gastos de comisionados y del costo de hacer una exposición. Lo que parece claro es que el gobier-

58 Carta de Carlos Holguín a Dn. Antonio Cánovas del Castillo, 13 de diciembre de 1891, AGA, Presidencia, caja 3602.

59 El Tesoro de los Quimbayas se expuso en el Museo Arqueológico Nacional de España desde su donación en 1893 hasta 1945, año en que fue trasladado al Museo de América de Madrid. La lista de los objetos donados consta en el Libro de registro de donaciones del Museo Arqueológico Nacional de España. La colección consta de 122 piezas de orfebrería de oro de objetos corporales y piezas de uso ceremonial. Seis estatuillas antropomorfas (4 masculinas y dos femeninas) y una cabeza son las piezas más sobresalientes del tesoro. La colección de objetos que Colombia presentó en la Exposición Histórico-Americana contenía, en su totalidad, 1.012 piezas de las cuales 818 eran de oro, 383 de cobre y 133 de cerámica, más 44 copias fotográficas inéditas de otras tantas figuras de oro. Restrepo y Tirado e Arias, 1892. Conviene senalar que para la Exposición Italo-Americana de Génova de 1892, Colombia envió el catálogo Antichitá Colombiane degli Aborigen formado por 92 láminas con fotografías de varias piezas del tesoro. Gamboa Hinestrosa, 2002: 174.

60 Según consta en el «Contrato sobre compra de una colección de objetos de oro» entre el Gobierno y Fabio Lozano Torrijos, se pagó a este último la suma de 70.000 pesos. Tomado de Gamboa Hinestrosa, 2002: 148. Al parecer, en Colombia, la compra del Tesoro de los Quimbayas se mantuvo en el mayor secreto posible y no fue sino hasta el 20 de julio de 1892 que Carlos Holguín, en su mensaje a las cámaras legislativas, informó de la adquisición del tesoro para exhibirlo y donarlo. Gamboa Hinestrosa, 2002: 179. 
no de Colombia no desea tomar parte en la Feria ${ }^{61}$. Los reproches suben de tono pues no sólo se añade que Colombia es la única que pierde con su política de no adoptar la reciprocidad con Estados Unidos, sino que a éste poco le importa que Colombia estuviese representada en la Feria la cual perdería muy poco, mientras que aquélla lo perdería todo.

La respuesta colombiana, en un tono irónico sorprendente, no tardó en llegar. El editorial «Pro Patria» de El Criterio arguyó que el encono de The Herald era prematuro ya que aún no se había celebrado la exposición. Y, añadía, si los Estados Unidos «tienen otros mercados en donde comprar café, nosotros tenemos también otros países en donde venderlo». Asimismo, preguntaba: "¿Se habría permitido el airado periódico esa expresión depresiva é hiriente si se hubiera tratado de Inglaterra? ¡Valiente prueba de poderío y entereza la que da el diario americano insultando á Colombia!». El editorial finalizaba diciendo que si bien el diario colombiano no era un órgano oficial, al menos sí era un vocero de la patria insultada y, por lo mismo, no tenía «por qué observar ciertas reservas gubernamentales, ni por qué dejarles pasar sin respuesta á los periódicos extranjeros, las insolencias que se permitan con la República, nuestra madre» ${ }^{62}$.

Quizás la controversia periodística sólo quedó en eso: una controversia entre particulares. Sin embargo, y al parecer, el Tesoro de los Quimbayas no fue expuesto en su totalidad en Chicago. Esta notoria ausencia tiene un trasfondo político. En lo que se refiere a la política interior colombiana muestra la desavenencia entre Fidel Pombo, director del Museo Nacional, y Vicente Restrepo, encargado de la Subcomisión de Prehistoria e Historia Americana de la Comisión de las Exposiciones de Madrid y Chicago ${ }^{63}$. También deja al descubierto la disputa entre distintas facciones políticas que rivalizaban por una u otra exposición según sus intereses; los seguidores de Carlos Holguín apostaban por la Exposición de Madrid, los opositores al gobierno de Holguín dirigieron sus intereses a la Exposición de Chicago. Con relación a la política exterior muestra, por un lado, que el carácter comercial de la Exposición de Chicago despertó poco interés en el gobierno colombiano. Por otro, que en el contexto de la rivalidad suscitada por la celebración de las dos exposiciones internacionales

61 «Pro Patria», I/123 (Bogotá, 13 de agosto de 1892): 2, AGA, Relaciones Exteriores, caja 1286. En la nota del diario neoyorquino se dice que el gobierno de Colombia compró la colección de objetos de oro por valor de $\$ 60,000$, cantidad que se restó a los $\$ 100,000$ asignados a la comisión preparatoria de las exposiciones de Madrid y de Chicago.

62 «Pro Patria», I/123 (Bogotá, 13 de agosto de 1892): 2.

63 Para conocer los entresijos de la disputa entre Fidel Pombo y Vicente Restrepo: Gamboa Hinestrosa, 2002: 170-176. 
Colombia defendió la idea más conservadora de la hispanidad, reafirmó su lealtad a España y menospreció, por así decirlo, la política panamericana de Estados Unidos. Así pues, España ratificaba aún su liderazgo en América Latina.

Ahora bien, ¿qué sucedía en México?, ¿por qué el gobierno de Porfirio Díaz puso en marcha todo ese entramado cultural para participar en los festejos del IV Centenario del Descubrimiento de América?, ¿cuál fue la apuesta del gobierno mexicano y de sus ilustres intelectuales?

El Porfiriato, caracterizado por esa paz inusitada y ese interés por modernizar el país, no estuvo exento del juego diplomático que representó la celebración de la gesta colombina. El gobierno del general Díaz diseñaría una estrategia diplomática que le permitiría fomentar su política bilateral con Estados Unidos a la vez que buscar «el múltiple acercamiento -industrial, comercial, financiero, cultural - a Europa, como recurso equilibrador frente a los Estados Unidos» ${ }^{64}$. La participación de México en los festejos del IV Centenario es una muestra palpable no sólo de la política exterior porfiriana que miraba con cierto recelo el panamericanismo liderado por Estados Unidos, sino de aquellos intelectuales que simpatizaban con España y su política hispanoamericana más progresista, aquella que buscaba en las relaciones culturales el fundamento de las nuevas relaciones entre España y las repúblicas americanas. En este marco de rivalidad no resulta extraño que México apostara, de manera significativa, por los festejos españoles.

Tampoco resulta fortuito, nada fortuito, ni la elección de la Junta Colombina ni su lugar de trabajo: el Museo Nacional. Intelectuales como Vicente Riva Palacio, Francisco del Paso y Troncoso, José María Vígil, Joaquín García Icazbalceta o Jesús Galindo y Villa representan el ala más liberal (¿o menos conservadora?) del ambiente intelectual mexicano de fines del siglo XIX. El Museo Nacional constituye, como bien señala Jesús Bustamante, la institución desde la cual se lanza «una portentosa campaña para difundir una imagen de la naturaleza, de los hombres, el pasado y el presente de la República Mexicana» ${ }^{65}$, cuyo principal objetivo era que México, y su gobierno, fuesen reconocidos a nivel internacional. Reconocimiento no sólo en el ámbito político, social o económico, sino en el científico. Y es ahí, en el ámbito científico, donde la participación de México en la Exposición Histórico-Americana ${ }^{66}$ recupera su

64 Krauze, 1987: 47-48.

65 Bustamante García, LXV/234 (Madrid, 2005): 303-318. Es preciso recordar que Francisco del Paso y Troncoso fue director del Museo Nacional de 1889 a julio de 1892. De julio de 1892 a 1916, fungió como director del museo en misión en Europa.

66 No era la primera vez que México participaba en una exposición internacional. Ya lo 
singularidad e importancia ya que demostró la modernidad de la ciencia mexicana, impulsó las investigaciones y publicaciones de carácter científico y marcó la pauta de la primera gran reestructuración que sufrió el Museo Nacional con miras a la celebración, en suelo mexicano, del XI Congreso Internacional de Americanistas en 1895, el primero que se celebró en tierras americanas ${ }^{67}$. Reestructuración que, a su vez, permitió el desarrollo y anclaje institucional de la incipiente antropología mexicana.

\section{LA EXPOSICIÓN HISTÓRICO-AMERICANA COMO CATALIZADOR DE LA ANTROPOLOGÍA MEXICANA}

Para entender a cabalidad la relevancia nada despreciable, por cierto, de la Sección de México en la Exposición de Madrid hay que remontarse, desde luego, a la década de los años ochenta con especial énfasis en los dos últimos años, cuando Francisco del Paso y Troncoso fue nombrado visitador del Museo Nacional (1888), para luego asumir su dirección (1889). A partir de este año los contenidos del museo adquirieron el carácter arqueológico ${ }^{68} \mathrm{e}$ histórico que le caracterizó durante las siguientes dos décadas aunque, hay que decirlo, en octubre de 1895 se creó la sección de Antropología y Etnografía la cual resultó de vital trascendencia para la transformación definitiva del museo a partir de 1909 con miras a la celebración, en su seno, del XVII Congreso Internacional de Americanistas que coincidió con la conmemoración del Centenario de la Independencia en 1910. Año éste, por cierto, en el que se retiraron de las instalaciones y acervos del museo las colecciones de historia natural y se reinauguró como Museo Nacional de Arqueología, Historia y Etnología ${ }^{69}$.

había hecho en la Exposición Universal de Nueva Orleáns (1885); la del Centenario de la Revolución Francesa en París (1889). Lo continuaría haciendo en la Exposición Universal de Chicago (1893); la Exposición Internacional de París (1900); la Exposición Panamericana de Búfalo (1901), entre muchas más. Lo que diferencia a la Exposición Histórico-Americana de Madrid del resto de las exposiciones que se llevaron a cabo en la segunda mitad del siglo XIX es su marcado carácter histórico, antropológico y arqueológico.

67 En realidad, este Congreso se celebró como un período extraordinario de sesiones. Como no pudieron celebrarse ni el que debía ser el XI Congreso de Americanistas en La Haya en 1896 ni la reunión propuesta para Portugal en 1897, el Congreso extraordinario de México se convirtió en el XI Congreso Internacional de Americanistas. Comas, 1974.

68 Es verdad que el 6 de julio de 1866 el Museo Nacional Mexicano, fundado en 1825, se inauguraba bajo el nombre de Museo Público de Historia Natural, Arqueología e Historia. Era la primera vez que se sustituía «la idea de antigüedades por el concepto moderno de arqueología». Rico Mansard, 2004: 205.

69 Para una historia del Museo Nacional pueden consultarse: Galindo y Villa, 1886. Cas- 
La llegada de Del Paso y Troncoso al Museo Nacional supuso el maridaje entre la arqueología y la historia ya que fue el primero en proponer, y llevar a cabo, una lectura minuciosa del pasado mexicano a partir de códices y documentos antiguos que, hasta entonces, se habían considerado de escaso valor para entenderlo o se desconocían por completo. De igual forma, estimaba que las referencias etnográficas y lingüísticas complementaban los estudios sobre el pasado indígena de México. Por lo mismo, buscó mayores espacios institucionales y académicos para fomentar los estudios arqueológicos, históricos y de «lengua mexicana». No en balde, su primera gran reforma fue el ambicioso programa de publicaciones que propuso con el fin de difundir las piezas arqueológicas que se encontraban en el Museo Nacional, los estudios sobre historia prehispánica que se llevaban a cabo en el propio museo; así como el rescate de documentos y obras antiguas esenciales para el estudio del náhuatl. Es pertinente recordar que ya desde 1886 Francisco del Paso y Troncoso por invitación expresa de Jesús Sánchez, quien fuera director del museo de 1883 a 1889, dirigía la Colección de gramáticas de la lengua mexicana, serie dedicada a sacar a la luz varias obras tanto nacionales como extranjeras, antiguas o modernas, de gran utilidad para el estudio de las lenguas indígenas de México $^{70}$.

También reformó la estructura y los contenidos de los célebres Anales del Museo Nacional que para ese entonces gozaban de gran éxito. Bajo el nuevo

tro-Leal y Sierra, 1988, vol. 7: 511-559. Morales Moreno, 1994. Rico Mansard, 2004. Y el excelente artículo de Bustamante García, LXV/234 (Madrid, 2005): 303-318.

70 En 1887, Del Paso y Troncoso dio a conocer el contenido del volumen primero de la Colección de gramáticas de la lengua mexicana. Dicho volumen constituía, al mismo tiempo, el primer tomo del Apéndice a los Anales del Museo. La colección estaría integrada por tres tomos de textos y un tomo para los estudios complementarios. Se reeditaron, por ejemplo, el Arte Mexicana del padre Antonio del Rincón, publicado por primera vez en 1595, reimpreso en 1885 por Antonio Peñafiel y en 1888 por el Museo Nacional. El Arte Mexicana de fray Diego de Galdo Guzmán el cual apareció por primera vez en 1642 y fue reimpreso por el museo en 1890; el Arte de la lengua mexicana con la declaración de los adverbios della del padre Horacio Carocci que Del Paso y Troncoso dejó en prensa antes de partir a España y se publicó a finales de 1892; El Arte de la lengua mexicana y castellana compuesto por el padre Alonso de Molina (1571) y reeditado por el museo en 1886; el Arte para aprender la lengua mexicana, compuesto por Fr. Andrés de Olmos (1547) y reeditado por el museo en 1885; así como, el Arte de la lengua mexicana de Agustín de Vetancurt aparecida en 1673 y reeditada por el museo en fecha muy posterior (1901-1904) a las mencionadas. Esta serie de gramáticas, publicada en fascículos en los apéndices de números sucesivos de los Anales del Museo Nacional, quedaron recogidas en el volumen: Del Paso y Troncoso y González Obregón, 1904 (comunicación personal de Jesús Bustamante). Para más información pueden verse: Del Paso y Troncoso, III (México, 1886): 321-324; IV (México, 1887): 260-272. Galindo y Villa, I (México, 1922): 305-579. Cline, 1973, vol. 13: 370-427. 
plan, el tomo V de la primera época de los Anales estuvo dedicado a la interpretación del Códice Borgiano, obra póstuma del padre José Lino Fábrega. Del Paso y Troncoso incluyó todo el texto original en italiano cotejado con la versión en castellano que él mismo hiciera. El tomo VI sólo incluyó Idolatrías y Supersticiones de Indios (1892-1900), en seis piezas. El plan de publicaciones quedó truncado cuando Francisco del Paso y Troncoso partió con destino a España para, primero, montar la sección mexicana de la Exposición Histórico-Americana y, después, radicar en Europa con el propósito de cumplir su extraordinaria «misión en Europa» ${ }^{71}$, cuya finalidad fue compilar, copiar, interpretar, y más tarde publicar, el mayor número de documentos antiguos sobre el pasado mexicano que poseían bibliotecas, archivos y museos europeos. Resultado de esta formidable misión fue la publicación, en 1906-1907, de la edición fototípica de la Historia de las Cosas de la Nueva España de fray Bernardino de Sahagún, además de las colecciones Papeles de la Nueva España (1905) y Epistolario de la Nueva España (1939-1942).

Y aunque el plan original de publicaciones propuesto por Del Paso y Troncoso no se llevó a cabo en su totalidad, los siguientes directores del museo continuaron fomentando la labor editorial del mismo. Las publicaciones del Museo Nacional alcanzaron un elevado prestigio internacional no sólo por el cuidado y la calidad de las obras editadas, sino por el alto nivel científico de sus contenidos. Se editaron múltiples ensayos, descripciones, bosquejos o escritos que abarcaban desde temas naturales hasta históricos o prehispánicos, estos últimos con un claro predominio en las temáticas a tratar. Se reprodujeron diccionarios y vocabularios indígenas; así como infinidad de obras relacionadas con el mundo prehispánico y de los primeros años de la colonia. Se publicaron, además, gran variedad de Catálogos y Guías ${ }^{72}$ tanto de los fondos como de las salas de exhibición del museo. De igual forma, los Anales del Museo, revista trimestral aparecida en 1877, se transformaron en la publicación de mayor trascendencia y prestigio nacional e internacional ya que se volvieron una referencia obligada para los estudiosos de las lenguas indígenas pues en diversas ocasiones se publicaron en sus páginas vocabularios, diccionarios y gramáticas de lenguas indígenas ${ }^{73}$. Los Anales del Museo y la revista $\mathrm{La} \mathrm{Na-}$

71 Cfr. Zavala, 1938.

72 Se editaron, entre otros: Mendoza y Sánchez, 1882. Galindo y Villa, 1896; 1897. Herrera y Cicero, 1894. Ramírez, 1896. También se editaron catálogos con las colecciones de mamíferos, aves, reptiles, batracios, coleópteros, peces o minerales que se encontraban en las salas del Museo Nacional.

73 Para las publicaciones del Museo Nacional pueden consultarse: Iguiniz, 1912. Castillo Ledón, 1 (México, 1922): 3-6. Pompa y Pompa, 1962. Mejía Sánchez, 1988, vol. 8: 211-236. Rico Mansard, 2004. 
turaleza, publicación de la Sociedad Mexicana de Historia Natural, ayudaron a aumentar la presencia internacional del museo ya que fueron utilizadas como «cartas de presentación y medios de intercambio institucional» ${ }^{74}$ que fortalecieron las relaciones con el Instituto Smithsoniano de Washington; la Société d'Anthropologie de París; el Instituto Geográfico Argentino de Buenos Aires; el Museo de Historia Natural de Viena; la Academia Leopoldina de Ciencias Naturales de Dresden, Alemania, y la Societá Romana di Antropologia, por citar algunas ${ }^{75}$.

La segunda gran reforma emprendida fue, sin duda alguna, el impulso dado a las expediciones científicas con el fin de potenciar la investigación arqueológica y enriquecer considerablemente los fondos del museo. Ya no se trataba de comprar colecciones o recibir donaciones y remisiones de objetos, sino de investigar in situ las piezas y zonas arqueológicas. Como resultado de ello, y a raíz de la decisión del gobierno mexicano de participar en la Exposición Histórico-Americana, la sección de Arqueología aumentó de forma considerable sus colecciones. La expedición científica de mayor envergadura fue la que llevó a cabo el propio Del Paso y Troncoso en Cempoala, Veracruz. Dicha expedición, como ya mostré en las primeras páginas de este artículo, constituyó el corpus principal de la sección mexicana que, a decir de Jesús Galindo y Villa, fue «la más rica y la más importante por la cantidad y el interés científico de los objetos pre-colombinos que se presentaron $\rangle^{76}$.

Las reformas no sólo respondieron al interés muy particular de Francisco del Paso y Troncoso por la arqueología y la historia mexicanas, sino que lo hicieron conforme a unos intereses políticos que además de servir como fundamento político de la campaña internacional lanzada por el gobierno de Porfirio Díaz para dar a conocer la estabilidad y el progreso del México moderno; sirvieron para difundir la imagen de un mundo prehispánico majestuoso. Con ello se trataba de demostrar que el pasado mexicano era tan ancestral y remoto como el de Egipto, Grecia o Roma. En otras palabras, la grandeza del pasado mexicano se remontaba a la época de las grandes culturas de la antigüedad clásica. Ahora bien, dotar de clasicismo ${ }^{77}$ al pasado mexicano no fue un asunto

74 Rico Mansard, 2004: 216.

75 El Museo Nacional mantenía estrechos contactos con sesenta y cuatro instituciones internacionales. Saldaña y Cuevas Cardona, 12/13 (México, septiembre/diciembre 1999): 309-332.

76 Galindo y Villa, I (México, 1922): 345.

77 El clasicismo histórico otorgado al pasado mexicano no era nuevo. Fue recurrente en pensadores novohispanos como el jesuita Francisco Javier Clavijero. Casi un siglo después, las exploraciones llevadas a cabo por científicos europeos, en especial franceses, en la región maya del país ayudaron a reafirmar la idea de que la historia de México era tan antigua como la 
banal pues si bien se hacía en un momento en el que la glorificación del pasado servía para establecer el puente «natural» entre el pasado indígena milenario y la nación moderna porfiriana; no menos cierto es que con ello se intentaba mostrar que México, y sus culturas prehispánicas, no eran inferiores a otras culturas que, como la romana o la griega, se consideraban los pilares de la civilización occidental. La apuesta porfiriana por el pasado indígena se enfrentaba, también, a aquellos historiadores mexicanos de filiación hispanista que en años anteriores se habían dedicado a resaltar los rasgos negativos de las culturas prehispánicas.

Aunados a estos intereses políticos existían otras realidades de carácter científico que sirvieron para mostrar que, al menos, cierta ciencia mexicana se encontraba a la par de la ciencia de las principales naciones occidentales, pues sus contribuciones tenían un alto nivel científico el cual era reconocido, incluso, en los ámbitos científicos europeos o norteamericano. Baste mencionar la gran variedad de estudios estadísticos que México presentó en la Exposición de París de 1889; así como los mapas y cálculos geodésicos, topográficos y geográficos del país que «la comunidad científica francesa destacó y alabó» ${ }^{78}$. Es inevitable mencionar el trabajo realizado por los médicos poblanos Francisco Martínez Baca y Manuel Vergara en el departamento de Antropología Criminal de la penitenciaría de varones del estado de Puebla. El extenso trabajo quedó recogido en el libro Estudios de antropología criminal, el cual no sólo fue premiado en la World's Columbian Exposition of Chicago (1893), sino que fue elogiado y aprobado por el célebre criminólogo italiano Cesare Lombroso quien, incluso, ofreció traducirlo al italiano y al francés ${ }^{79}$.

Realidades científicas que, por cierto, marcaron de manera significativa las directrices a corto, mediano y largo plazo de la antropología mexicana. Estas realidades quedaron plasmadas en tres ámbitos distintos relacionados entre sí. El primero, en la rica y muy singular colección de objetos arqueológicos, antropológicos e históricos que México presentó en Madrid (y después en Chica-

griega, la romana o la egipcia. Resultaron significativos para esta idea la traducción que hiciera el abate Brasseur de Bourbourg del manuscrito original del Popol-Vuh en 1859; o el descubrimiento en 1873 del Chac Mool en Chichén Itzá por Augusto Le Plongeon. Todo ello fue recogido, de alguna u otra manera, por historiadores e intelectuales como Alfredo Chavero, Manuel Orozco y Berra, Joaquín García Icazbalceta, Vicente Riva Palacio, José María Vígil o Francisco del Paso y Troncoso cuyas aportaciones en el campo de la arqueología, las lenguas indígenas y la historia de las culturas prehispánicas resultaron ser de suma importancia para apuntalar este clasicismo.

78 Tenorio Trillo, 1998: 183.

79 Monroy, LII (Puebla, 6 de junio de 1893): 141-142. Para conocer en detalle el trabajo de los médicos poblanos: Martínez Baca y Vergara, 1892. Cruz Barrera, 1999. 
go); así como en la inmensa colección de fotografías de «tipos del país» que acompañó a los objetos enviados ${ }^{80}$. Dicha colección, como bien señala Georgina Rodríguez, representó el primer «mapeo etnográfico» realizado en México a partir de fotografías ${ }^{81}$ cuya finalidad era mostrar la gran diversidad étnica del país y establecer los estereotipos nacionales. La habilitación del taller de fotografía con motivo de la Exposición de Madrid significó no sólo la incorporación de una técnica que surgía a la par de la ciencia antropológica, sino que la antropología mexicana en particular incorporaba una herramienta de inestimable valor para su consolidación. Este taller, por ejemplo, resultó ser fundamental para los estudios antropométricos que Nicolás León impulsó, y llevó a cabo, cuando fue director (1900-1907) del departamento de Antropología Física del museo ${ }^{82}$.

A raíz de la participación de México en la exposición de Madrid y con miras a celebrar, en las instalaciones del museo, el XI Congreso de Americanistas la institución sufre una primera reestructuración donde se observa, con bastante nitidez, el segundo ámbito de incidencia de estas nuevas realidades científicas, esto es: en las secciones, en los contenidos, en las salas e, incluso, en el espacio físico del museo. Reestructuración que se vio reflejada, por ejemplo, en la remodelación del departamento Histórico y Arqueológico y en la apertura de nuevas secciones como la de Antropología y Etnografía ${ }^{83}$. En efecto, en 1892 el entonces secretario de Justicia e Instrucción Pública, Joaquín Baranda, propuso que en el Museo Nacional se acondicionara una sala dedicada por entero a exhibir piezas antropológicas y etnográficas. El nuevo departamento, cuya dirección estuvo a cargo de Alfonso L. Herrera y su ayudante Ricardo E. Cicero, incluía un extenso plan de exploraciones científicas ${ }^{84}$. Es pertinente señalar que Jesús Galindo y Villa, a su regreso de Madrid en 1893, se hizo cargo

80 Varias de las colecciones fotográficas de ruinas y tipos indígenas expuestas en la Sección de México fueron premiadas al culminar la Exposición Histórico-Americana. Los estados que ganaron medallas por sus colecciones fotográficas fueron: Yucatán, medalla de oro por su colección de fotografías de las ruinas arqueológicas del Estado. Por sus colecciones de tipos indígenas: Michoacán (medalla de plata), Morelos (medalla de plata), Chiapas (medalla de cobre), Guerrero (medalla de cobre), Territorio de la Baja California (medalla de cobre). Sonora (mención honorífica), Chihuahua (mención honorífica), Nuevo León (mención honorífica), Colima (mención honorífica), Guanajuato (mención honorífica) y Querétaro (mención honorífica).

81 Rodríguez Hernández, 13 (México, septiembre/diciembre 1997): 27.

82 León, I (México, 1922): 99-136.

83 Otras secciones fueron la de Anatomía comparada, Teratología o monstruosidades, Botánica y Zoología aplicadas. Galindo y Villa, 1893.

84 Galindo y Villa, 40/2-6 (México, enero/junio 1922): 301-341. También puede verse Rico Mansard, 2004: 168. 
del departamento Histórico y Arqueológico el cual ordenó metódicamente «aprovechando cuantos elementos se habían utilizado en la Sección Mexicana de la Exposición Histórico-Americana» ${ }^{85}$.

Así las cosas, en 1895, con motivo del Congreso Americanista, el Museo Nacional estrenó su nueva imagen. El departamento de Arqueología mostraba su remodelada Galería de Monolitos. La nueva sección de Antropología y Etnografía, inaugurada en 1895, contenía gran parte de las colecciones osteológicas y de cráneos que se adquirieron para la exposición de Madrid; muchos de los utensilios y piezas de vestir que fueron remitidos al Museo Nacional para ampliar las colecciones enviadas a Madrid, amén de una impresionante colección de fotografías que incluía, por supuesto, las series fotográficas que se habían remitido a Madrid tres años antes. La nueva colección fotográfica estaba formada por 1645 imágenes, de las cuales 478 eran de tipos indígenas y aspectos culturales de varios grupos étnicos del país y 1167 registraban algunos aspectos de la cultura material de dichos grupos, así como animales, plantas, formaciones rocosas y panorámicas de comunidades y rancherías ${ }^{86}$. Con esta nueva sección, el museo abrió sus puertas a los estudios antropológicos que vinieron a complementar los estudios arqueológicos e históricos.

Como consecuencia de todo lo anterior, el tercer ámbito de incidencia, cuyos resultados pueden verse a más largo plazo, se vio reflejado en la institucionalización, desarrollo, y posterior profesionalización, de la naciente, y muy peculiar, antropología mexicana cuyo espacio natural de consolidación fue, precisamente, el Museo Nacional. Así pues, en mayo de 1905 la Secretaría de Instrucción Pública y Bellas Artes con Justo Sierra a la cabeza facultó al Museo Nacional como centro de enseñanza formal. Bajo la subdirección de Francisco M. Rodríguez, se llevó a cabo el viejo anhelo de anteriores directores, como Manuel Urbina o Alfredo Chavero, de transformar el museo en una institución de enseñanza especializada donde se profesionalizaran arqueólogos, historiadores y etnólogos que aprenderían, desde luego, arqueología, historia, etnología e «idioma mexicano». Los cursos iniciaron de manera formal en enero de 1906. Nicolás León elaboró el programa de etnología, Genaro García el de historia, Jesús Galindo y Villa el de arqueología y Mariano Sánchez el de «idioma mexicano» el cual quedó incorporado tiempo después al programa de estudios ${ }^{87}$.

85 Galindo y Villa, 40/2-6 (México, enero/junio 1922): 321.

86 Véanse: Galindo y Villa, 40/2-6 (México, enero/junio 1922): 321-322; Gutiérrez Ruvalcaba, 2/5 (México, enero/abril 1999): 17-25.

87 Rico Mansard, 2004: 245 y ss. Las clases continuaron en la sede del museo hasta 1916, año en que fueron trasladadas a la Escuela Nacional de Altos Estudios a raíz de una propuesta que hiciera Jesús Galindo y Villa en abril de 1915. 
Pero, y esto es a mi parecer lo más importante de la participación de México en la Exposición Histórico-Americana con sus consecuentes reformas y reestructuraciones, todo ello se hizo, justo, en un momento en el que otras tradiciones antropológicas definían sus intereses hacia adentro, esto es, hacia el estudio de sus propias poblaciones ${ }^{88}$. México, al igual que Italia, Alemania o Estados Unidos, optaba por el estudio de su población en un contexto en el que, también, se estaba llevando a cabo el proceso de construcción nacional donde no sólo había que homogeneizar y estandarizar unas costumbres, una historia, una lengua y una cultura para hacerlas nacionales, sino que había que estandarizar, racionalizar y clasificar a la población para convertirla en nacional. Tiempos en los que había que demostrar que la población mexicana era tan «normal» como las poblaciones de otros países (léase europeos). Tiempos, también, en los que el crecimiento poblacional aumentaba considerablemente en las ciudades y se planteaban las mejoras sanitarias e higiénicas de las ciudades para garantizar la salud de sus habitantes. Tiempos aquellos en los que había que sistematizar los códigos civiles, penales, procesales o comerciales para garantizar los deberes y derechos de toda la población. Tiempos, por supuesto, en los que la ciencia era considerada condición sine qua non para progresar. Tiempos, en fin, en los que la antropología mexicana y, quizás, la ciencia mexicana mostraban su impresionante modernidad.

\section{BIBLIOGRAFÍA}

Ardao, Arturo, «Panamericanismo y latinoamericanismo», Leopoldo Zea (comp.), América Latina en sus ideas, México, Siglo XXI, 1986: 157-171.

Arriaga, Víctor A., «México y los inicios del movimiento panamericano, 1889-1890», Roberto Blancarte (comp.), Cultura e identidad nacional, México, CNCA/FCE, 1994: 107-126.

Badger, R. Reid, The Great American Fair. The World's Columbian Exposition and American Culture, Chicago, Nelson Hall, 1979.

Bernabéu Albert, Salvador, «El IV Centenario del descubrimiento de América en la coyuntura finisecular: 1880-1893», Revista de Indias, XLIV/174 (Madrid, 1984): 345-366.

Bernabéu Albert, Salvador, 1892: El IV Centenario del descubrimiento de América en España, Madrid, CSIC, 1987.

88 Bustamante García, LXV/234 (Madrid, 2005): 314-315. 
Bernabéu Albert, Salvador (estudio preliminar), IX Congreso Internacional de Americanistas. Actas de la Novena Reunión, Huelva 1892 (facsímil de la primera edición), España, Ayuntamiento de Palos de la Frontera, 2006: 9-65.

Bustamante García, Jesús, «La conformación de la Antropología como disciplina científica, el Museo Nacional de México y los Congresos Internacionales de Americanistas», Jesús Bustamante (coord.), Dossier: Ingenieros sociales en América Latina: el papel de la Antropología y su institucionalización en las nuevas repúblicas», Revista de Indias, LXV/234 (Madrid, 2005): 303-318.

Calderón Quijano, José Antonio, El IV Centenario del descubrimiento en La Ilustración Española y Americana y en el Ateneo de Madrid, Sevilla, Escuela de Estudios Hispanoamericanos, 1986.

Calderón Quijano, José Antonio, «El IV Centenario del descubrimiento de América», Boletín de Bellas Artes, 18 (Sevilla, 1990): 93-166.

Castillo Ledón, Luis, «Las publicaciones del Museo», Anales del Museo Nacional de Arqueología, Historia y Etnografia, 1 (México, 1922): 3-6.

Castro-Leal, Marcia y Sierra, Dora, «Museo Nacional de Antropología», Carlos García Mora (coord.), La antropología en México. Panorama histórico, México, INAH, 1988, vol. 7: 511-559.

Cline, Howard F., «Selected Nineteenth-Century Mexican Writers on Ethnohistory», Robert Wauchope (ed.), Handbook of Middle American Indians, vol. 13, Austin, University of Texas Press, 1973: 370-427.

Comas, Juan, Cien años de Congresos Internacionales de Americanistas. Ensayo histórico-crítico y bibliográfico, México, UNAM, 1974.

Connell-Smith, Gordon, El sistema interamericano, México, FCE, 1982.

Cruz Barrera, Nydia E., Las ciencias del hombre en el México decimonónico. La expansión del confinamiento, Puebla, BUAP, 1999.

Curti, Merle, «America at the World Fairs, 1851-1893», The American Historical Review, 55/4 (USA, 1950): 833-856.

Del Paso y Troncoso, Francisco, «Lingüística de la República Mexicana», Anales del Museo Nacional de Arqueología, III (México, 1886): 321-324.

Del Paso y Troncoso, Francisco, «Publicaciones del Museo Nacional de México», Anales del Museo Nacional de Arqueología, IV (México, 1887): 260-272.

Del Paso y Troncoso, Francisco, Exposición histórico-americana de Madrid. Catálogo de la Sección de México, tomo I, Madrid, Sucesores de Rivadeneyra, 1892a.

Del Paso y Troncoso, Francisco, Exposición histórico-americana de Madrid. Catálogo de la Sección de México, tomo II, Madrid, Sucesores de Rivadeneyra, 1892b. 
Del Paso y Troncoso, Francisco, Catálogo de la colección del Sr. Presbitero Dn. Francisco Plancarte formado con la colaboración del dueño por el Director del Museo Nacional de México, México, Imprenta de Ignacio Escalante, 1892c.

Del Paso y Troncoso, Francisco y Obregón, Luis González (eds.), Colección de gramáticas de la lengua mexicana, I, México, Imprenta del Museo Nacional, 1904.

Documentos Oficiales. Exposición Histórico-Europea de Madrid, El Centenario. Revista Ilustrada. Órgano Oficial de la Junta Directiva, II (Madrid, 1892): 181.

«Pro Patria», El Criterio. Diario de la tarde, I/123 (Bogotá, 13 de agosto de 1892): 2.

Fewkes, Jesse W., Catálogo de los objetos etnológicos y arqueológicos exhibidos por la expedición Hemenway, Madrid, Jaramillo Impresor, 1892.

Galindo y Villa, Jesús, «Exposición histórico-americana de Madrid de 1892. Nota relativa a la sección de la República Mexicana», Memorias de la Sociedad Científica «Antonio Alzate», VI (México, 1892-1893): 301-323.

Galindo y Villa, Jesús, Breve noticia histórico-descriptiva del Museo Nacional de México, México, Imprenta del Museo Nacional, 1893.

Galindo y Villa, Jesús, Guía para visitar los Salones de Historia, México, Imprenta del Museo Nacional, 1896.

Galindo y Villa, Jesús, Catálogo del Departamento de Arqueología, México, Imprenta del Museo Nacional, 1897.

Galindo y Villa, Jesús, «Las ruinas de Cempoala y del templo del Tajín (Estado de Veracruz), exploradas por el Director del Museo Nacional de Arqueología, Historia y Etnología en Misión en Europa, don Francisco del Paso y Troncoso», Anales del Museo Nacional de Arqueología, III (México, 1911): XCV-CLXI.

Galindo y Villa, Jesús, «Don Francisco del Paso y Troncoso. Su vida y sus obras», Anales del Museo Nacional de Arqueología, I (México, 1922): 305-579.

Galindo y Villa, Jesús, «El Museo Nacional de Arqueología, Historia y Etnología: breve reseña», Memorias y revista de la Sociedad Científica "Antonio Alzate», 40/2-6 (México, 1922): 301-341.

Gamboa Hinestrosa, Pablo, El Tesoro de los Quimbayas. Historia, identidad y patrimonio, Colombia, Planeta, 2002.

Granados, Aimer, Debates sobre España: el hispanoamericanismo en México a fines del siglo XIX, México, COLMEX/UAM-X, 2005.

Gutiérrez Ruvalcaba, Ignacio, «Antropólogos y agrónomos viajeros. Una aproximación», Alquimia, 2/5 (México, 1999): 17-25.

Handlin, Lilian, «Descubrimientos estadunidenses de Cristóbal Colón», Secuencia, 29 (México, 1994): 5-26.

Herrera, Alfonso L. y Cicero, Ricardo E., Catálogo de la Colección de Antropología del Museo Nacional, México, Imprenta del Museo Nacional, 1894. 
Iguiniz, Juan B., Las publicaciones del Museo Nacional de Arqueología, Historia y Etnología, México, Imprenta del Museo Nacional de Arqueología, Historia y Etnología, 1912.

Krauze, Enrique, Mistico de la autoridad. Porfirio Díaz, México, FCE, 1987.

León, Nicolás, «La antropología física y la antropometría en México. Notas históricas», Anales del Museo Nacional de Arqueología, Historia y Etnografía, 1 (México, 1922): 99-136.

López-Ocón, Leoncio, «El patriotismo liberal de Marcos Jiménez de la Espada en la conmemoración del IV Centenario de la empresa colombina», Antonio Lafuente y J. Sala Catalá (eds.), Ciencia colonial en América, Madrid, Alianza Editorial, 1992: 379-397.

López-Ocón, Leoncio, Biografía de «La América». Una crónica hispano-americana del liberalismo democrático español (1857-1886), Madrid, CSIC, 1987.

Mainer, José Carlos, La doma de la quimera. Ensayos sobre nacionalismo y cultura en España, Barcelona, Universitat Autonoma, 1988.

Martínez Baca, Francisco y Vergara, Manuel, Estudios de antropología criminal. Memoria, que por disposición del Superior Gobierno del Estado de Puebla presentan para concurrir a la Exposición Internacional de Chicago, Puebla, Imprenta, Litografía y Encuadernación de Benjamín Lara, 1892.

Mejía Sánchez, Mercedes, «Anales del Instituto Nacional de Antropología e Historia», Carlos García Mora (coord.), La antropología en México. Panorama histórico, México, INAH, 1988, vol. 8: 211-236.

Mendoza, Gumesindo y Sánchez, Jesús, Catálogo de las colecciones histórica y arqueológica del Museo Nacional de México, México, Imprenta de Ignacio Escalante, 1882.

Monroy, Atenedoro, «Una carta de Lombroso», Periódico Oficial del Gobierno del Estado de Puebla, LII (Puebla, 6 de junio de 1893): 141-142.

Morales Moreno, Luis Gerardo, Orígenes de la museología mexicana. Fuentes para el estudio histórico del Museo Nacional, 1780-1940, México, UIA, 1994.

Muriá, José María, «El IV Centenario del "descubrimiento de América”», Secuencia, 3 (México, 1985): 123-136.

Ortiz de Pinedo, Adelardo, «Las fiestas colombinas en Génova», El Centenario. Revista Ilustrada. Órgano Oficial de la Junta Directiva, II (Madrid, 1892): 85-92.

Pérez Bustamante, Ciriaco, «Sobre la génesis de la "Antología de poetas hispanoamericanos" de Menéndez Pelayo», Finisterre, III/1 (Madrid, 1948): 22-37.

Pike, Fredrick B., Hispanismo, 1898-1936. Spanish Conservatives and Liberals and their Relations with Spanish America, Notre Dame, University of Notre Dame Press, 1971. 
Pompa y Pompa, Antonio, El Instituto Nacional de Antropología e Historia. Su contribución a la bibliografía nacional, México, INAH, 1962.

Rama, Carlos M., Historia de las relaciones culturales entre España y la América Latina. Siglo XIX, México, FCE, 1982.

Ramírez, Román, Catálogo de las anomalías coleccionadas en el Museo Nacional precedido de unas nociones de Teratología, México, Imprenta del Museo Nacional, 1896.

Restrepo y Tirado, Ernesto y Arias, Isaac, Catálogo de los objetos que presenta el Gobierno de Colombia a la Exposición Histórico-Americana de Madrid, s.i, s.n, 1892.

Rico Mansard, Luisa Fernanda, Exhibir para educar. Objetos, colecciones y museos de la ciudad de México (1790-1910), Barcelona, Ediciones Pomares/CONACULTA, 2004.

Rodríguez, Miguel, «El 12 de octubre: entre el IV y el V Centenario», Roberto Blancarte (comp.), Cultura e identidad nacional, México, CNCA/FCE, 1994: 127-162.

Rodríguez Hernández, Georgina, «Miradas sin rendición», Luna Córnea, 13 (México, 1997): 25-31.

Rodríguez Hernández, Georgina, «Recobrando la presencia. Fotografía indigenista mexicana en la Exposición Histórico-Americana de 1892», Cuicuilco, 5/13 (México, 1998): 123-144.

Rydell, Robert W., All the World's a Fair. Visions of Empire at American International Expositions, 1876-1916, Chicago, University of Chicago Press, 1984.

Saldaña, Juan José y Cuevas Cardona, Consuelo, «La invención en México de la investigación científica profesional: el Museo Nacional 1868-1908», Quipu, 12/3 (México, 1999): 309-332.

Sánchez Díaz, Gerardo y Mijangos Díaz, Eduardo Nomelí, Las contribuciones michoacanas a la ciencia mexicana del siglo XIX, Morelia, UMSNH/Instituto de Investigaciones Históricas/Morevallado Editores, 1996.

Sepúlveda Muñoz, Isidro, Comunidad cultural e hispano-americanismo, 1885-1936, Madrid, UNED, 1994.

Sepúlveda Muñoz, Isidro, El sueño de la Madre Patria. Hispanoamericanismo y nacionalismo, Madrid, Fundación Carolina/Marcial Pons, 2005.

Tenorio Trillo, Mauricio, Artilugio de la nación moderna. México en las exposiciones universales, 1880-1930, México, FCE, 1998.

The Committee for the International Exposition of 1892, of the City of New York, Committee on Legislation, New York, Douglas Taylor, 1889.

Winthrop Bowen, Clarence, Christopher Columbus. 1492-1892, New York, 1889.

Revista de Indias, 2009, vol. LXIX, n. ${ }^{\circ} 246,273-306$, ISSN: 0034-8341

doi: 10.3989/revindias.2009.021 
Zavala, Silvio, Francisco del Paso y Troncoso: su misión en Europa, 1892-1916, México, Publicaciones del Museo Nacional, 1938.

Fecha de recepción: 11-4-2007

Fecha de aceptación: 22-11-2007

\section{THE HISTORICAL AMERICAN EXPOSITION OF MADRID IN 1892 AND THE ABSENCE (?) OF MEXICO}

The Fourth Centennial of the Discovery of America was celebrated in 1892. Together with the rest of the festivities, the Historical American Exposition of Madrid is considered a landmark not only for its political, cultural and scientific relevance, which, to this day, have not been studied in their entirety, but as well for the implications that resulted for Mexico. This article is meant to show, on the one side, the singularity of such festivities, and, on the other, the fact that Mexico's participation constituted an important historical moment for Mexican scientific anthropology. This research was essentially carried out based on the numerous documentation found at the Archivo General de la Administración, Alcalá de Henares.

Key words: Fourth Centennial, Historical American Exposition, National Museum of Mexico, anthropology. 